cause of detonation, though at one time it was considered that 'anti-knocks' acted by absorbing either the radiant energy or the electrons which by advance from the flame front increased the flame propagation and so led to detonation.

Bennett (1927), who studied the influence of substances on the ionisation of various flames and on ionisation during the slow combustion of a number of gas mixtures, found inter alia that leadtetra-ethyl, and iron carbonyl, as well as amyl nitrite, greatly increased the ionisation. It was considered, therefore, that ionisation was not a cause of detonation but merely a temperature effect.

\title{
Landlocked Salmon.
}

GOR many years there has existed in the middle and upper parts of the River Otra, in southern Norway, a fish known Jocally as the 'Blege,' a name applied throughout the whole of southwestern Norway chiefly to the juvenile stages of the sea trout. In fact an important fishery for the 'Blege' took place in old days in the southern parts of the Bygglandsfiord, a fishery mainly restricted to the spawning season late in the autumn and lasting until Christmas.

It is only recently ${ }^{1}$ that this fish has been discovered by Mr. Knut Dahl to be a true landlocked salmon (Salmo salar). Only exceptionally does this salmon exceed $30 \mathrm{~cm}$. (about $12 \mathrm{in}$.) in length, and for this reason $\mathrm{Mr}$. Dahl has called it a " Dwarfsalmon.' In general appearance it resembles an overgrown smolt, through the silvery coat of which the blue parr- or finger-marks are still faintly visible. An examination of such characters as the number of scales in the oblique row running backwards from the adipose fin to the lateral line, the shape and slenderness of the tail, and the short upper jaw, shows that it is indistinguishable from the young of typical migratory salmon, its only difference from the adult salmon being the retention of certain characters peculiar to the juvenile stages and its small size.

The adult fish are somewhat pelagic in their habits and roam about in schools all over the lake, unlike the ordinary trout, which appear to keep more to the shallow water and do not congregate

1 The "Blege" or Dwarf-salmon. A landlocked salmon from Lake Bygglandsfiord in Setesdal. By Knut Dahl. Skrifter utgitt av Det Norske Videnskaps-Akademi i Oslo. I. Matem.-Naturv. Klasse 1927. No. 9 . Oslo, 1927. so markedly in shoals. This roaming character is probably correlated with their feeding habits, since their food chiefly consists of the planktonic crustacean, Bosmina obtusirostris. Scale examination shows that many exhibit the typical growth periods of the migratory salmon, spending their first years in the river under poor feeding conditions, and then migrating into the lake where food is more abundant. Some, however, are born in the lake itself, and do not show this change in growth rate. A migratory habit is also exhibited by the landlocked salmon of Lake Wenern, which migrate into the river to spawn, returning afterwards to the lake, but unlike the dwarf-salmon they grow to a considerable size. Of the dwarf-salmon born under river conditions, the majority migrate after 2.5 winters. Most of the fish captured were of an age of four to six winters, and older fish were rare. Spawning took place for the first time generally in the fifth or sixth winter.

True salmon are prevented from migrating into these waters by high falls situated at Vigelandsfoss, 15 kilometres from the sea, and from geological evidence Mr. Dahl estimates that the dwarf-salmon must have arisen from fish landlocked about 9000 years ago.

At the present day the impression gained was that these fish were as numerous as the common trout, though the net fishing has diminished owing to the damming of the Bygglandsfiord as a reservoir. Mr. Dahl gives a vivid description of the sport afforded by the dwarf-salmon to the angler, and maintains that in fighting powers they surpass the trout, a supremacy which they hold also as a table delicacy.

\section{Research and Development in Australia.}

$\mathrm{T}^{\mathrm{H}}$ HE main objects of the Science and Industry Research Act (1926) of the Commonwealth Government were to reorganise the Institute of Science and Industry, which was founded in 1920, and to provide adequate funds for developing scientific and industrial research in Australia. The first Annual Report of the Council for Scientific and Industrial Research (Melbourne, 1927) contains a review of the activities of this newly constituted body between April 1926 and June 1927; the Science and Industry Research Act, 1920-26, is printed as an appendix to the Report. At the first meeting of the Council, it was decided to devote particular attention to investigations on plant and animal pests and diseases, fuel problems, preservation of foodstuffs, and forest products. In accordance with this decision, arrangements were made to secure information and reports on some of the problems concerned from Prof. T. G. B. Osborn (Adelaide), Prof. H. A. Woodruff (Melbourne), Dr. Franklin Kidd (Low Temperature Research Station, Cambridge), Mr. A. J. Gibson (Indian Forest Service), and other specialists. The various fields thus laid open to inquiry are all of first-rate importance, but a particular interest may perhaps be anticipated for Mr. Gibson's report, which is to deal with forest products problems and with the advisability of establishing a forest products laboratory in Australia.

The Annual Report affords a comprehensive summary of the many investigations in progress, some of which have already been noticed in the Council's journal (see NATuRE, Oct. 8, 1927, p. 520). Many of the activities of the Council have an intimate bearing upon the progress of agriculture in Australia. A standing committee on agriculture

No. 3046, VoL. 121] 